PERMIT REQUIREMENTS FOR DEVELOPMENT

OF

ENERGY AND OTHER SELECTED NATURAL RESOURCES

FOR THE

STATE OF MONTANA

PREPARED FOR

OLD WEST REGIONAL COMMISSION

AND THE

U.S. GEOLOGICAL SURVEY

BY J. K. SMITH

This material is the result of tax-supported research and as such it is not subject to copyright. It may be freely reprinted with customary credit to the source. None of the findings, conclusions, or recommendations in the data are endorsed by the old West Regional Commission, or the U.S. Geological Survey. 


\section{ACKNOWLEDGEMENTS}

The Montana Guide was prepared under the direction of the U.S. Geological Survey (USGS) in cooperation with the old West Regional Commission and the State of Montana. Funding support for this project was provided by the USGS Environmental Affairs Office (EAO). Wilbert J. Ulman and James Frederick of the USGS Resource Planning and Analysis Office (RPAO) served respectively as Program Manager and Project Coordinator during the preparation of the guidebook. Both the RPAO and EAO are under the Office of Earth Sciences Applications. Kenneth Blackburn, of the Old West Regional Commission, acted as Project Manager. Newell B. Anderson, Administrative Assistant, office of the Governor, served as State Representative and provided valuable technical assistance. Justus $\mathrm{K}$. Smith, AICP, of Denver, Colorado, was responsible for compiling all available information and producing the final document.

Request for information concerning this publication should be directed to either:

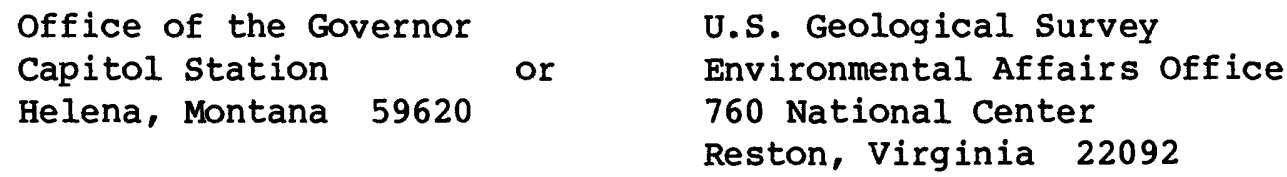

PUBLICATION AVAILABILITY

This Montana Permit Guide is available as an Open-File Report $\# 81-1267$ from:

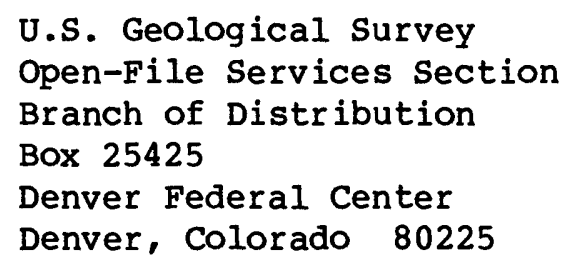




\section{TABLE OF CONTENTS}

\section{SECTION I.0 INTRODUCTION}

Introduction $\ldots \ldots \ldots \ldots \ldots \ldots \ldots \ldots \ldots \ldots \ldots \ldots \ldots \ldots \ldots \ldots \ldots$

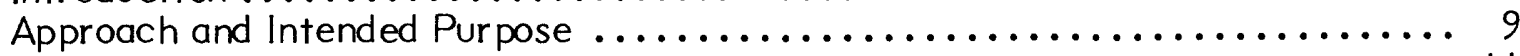

How to Use this Guidebook .............................. II

SECTION 2.0 STATE POLICY AND PROCEDURES

FOR CONSOLIDATED PERMIT PROGRAM

Chapter 2.1 State Environmental Policy Statutes ................ I5

\section{SECTION 3.0 RESOURCE EXTRACTION}

Chapter 3.1 Coal and Uranium Mining and Reclamation .............. 21

Chapter 3.2 Metalliferous and other Hard Rock Mining and Reclamation ..... 24

Chapter 3.3 Construction Materials Mining and Reclamation ........... 27

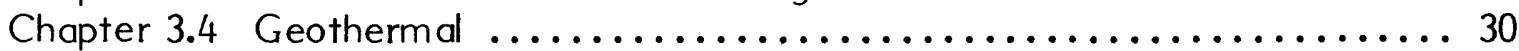

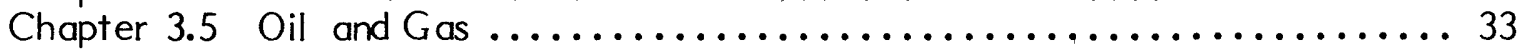

\section{SECTION 4.0 LAND USE REGULATION}

Chapter 4.I Major Facility Siting .......................... 39

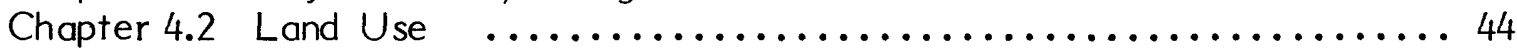

Chapter 4.3 Flood Plain Management....................... 46

\section{SECTION 5.0 ENVIRONMENTAL QUALITY MANAGEMENT}

Chapter 5.1 Air Quality .............................. 51

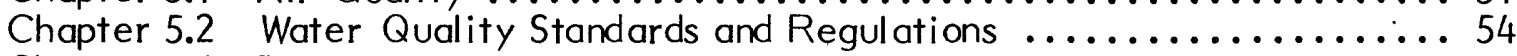

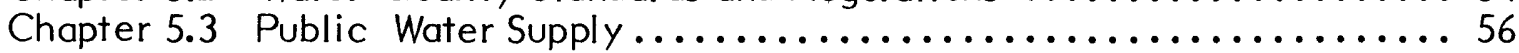

Chapter 5.4 In-situ Mining of Urani um Pollutant D ischarge ............. 58

Chapter 5.5 Solid Waste Management ........................ 61

Chapter 5.6 Hazardous/Toxic Waste Management ................... 64

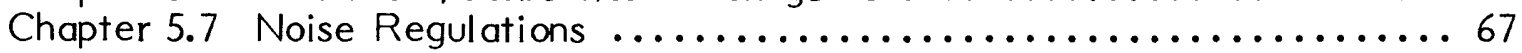

Chapter 5.8 Motor Vehicle Disposal $\ldots \ldots \ldots \ldots \ldots \ldots \ldots \ldots \ldots \ldots \ldots \ldots \ldots \ldots \ldots$

\section{SECTION 6.0 SOCIAL/ECOLOGICAL PRESERVATION}

Chapter 6.1 Rare, Threatened and Endangered Species ............. 73

Chapter 6.2 Archaeological and Historical ..................... 75

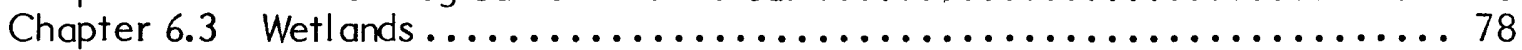

\section{SECTION 7.0 LOCAL REGULATORY POLICY}

Chapter 7.1 Local Government Land Use

and Natural Resource Control Enabling Laws .............. 83

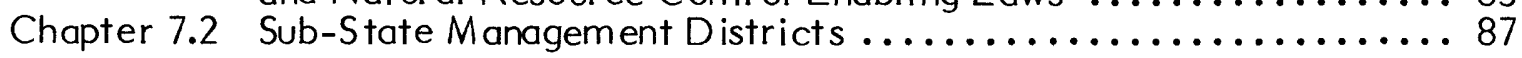




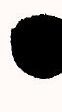


SECTION 1.0

INTRODUCTION 


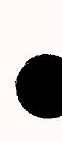

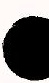




\section{INTRODUCTION}

This guide is one in a series prepared for various States. The purpose of the guidebook is to summarize environmental and land-use permits issued by the State for the development of energy and other natural resources. The guidebook is intended not only for private developers and interest groups, but al so for regulatory of ficials of Federal, State, and local government as well.

All State agencies having jurisdiction over the permits, licenses, and approvals described in this guidebook helped to prepare it, and they reviewed the final draft of each summary for accuracy and completeness. Users of this guidebook should be aware, however, that changes in the laws, rules and regulations, or regulatory personnel since the guidebook was published may cause signi ficant changes in permit requirements.

The guidebook should not be construed as a legal document or a final authority on permits for the State of Montana; it is not intended to be a comprehensive reference to the specific requirements of each permit, but to provide concise, easy-to-use information on the State regulations that govern the development of such resources. Before attempting to obtain a permit or begin any activity that might require a permit, persons should contact the appropriate State agency for fur ther details.

The guidebook is divided into seven sections. Sections 1, 2 and 7 discuss introductory information, consolidated permit programs for the State of Montana, and local regulatory policies, respectively. The remaining sections discuss permits that apply to Resource Extraction, Land Use Regulation, Environmental Quality Management, and Social/Ecological Preservation. Each section is divided into chapters; each chapter summarizes one permit, license, or approval. Permits administered by a single agency are generally grouped together in each section.

Each permit is discussed in the standard format shown below: 


\section{STANDARD FORMAT FOR PERMIT SUMMARY}

CHAPTER 0.0

TITLE OF ACTIVITY ADDRESSED BY PERMIT, LICENSE OR APPROVAL

INTRODUCTION

Description of administering agency and its role.

A. NAME OF PERMIT OR APPROVAL

Complete name of permit or approval.

B. STATUTORY AUTHORITY

Title of State statutes authorizing permit and the legal citations of each.

C. TITLE OF REGULATION

Title of State regulation(s) which apply to permit.

\section{SUMMARY OF PERMIT/APPROVAL PROCESS}

Summary of major steps involved in the permit/approval process.

I. APPLICABILITY.

Includes all types of activities which require the permit.

2. GENERAL REQUIREMENTS.

Conditions which must be met by the project sponsor before a permit can be acquired; does not include submissions or operations requirements.

3. SUBMISSION REQUIREMENTS.

Types of information which the project sponsor must include in the application for the permit.

4. PROCEDURE FOR OBTAINING PERMIT OR APPROVAL.

Includes information on items such as submittal procedures, completeness and technical review, public notice, comment and 
hearing periods, preliminary and final decisions, inspections, and processing time.

5. OPERATION REQUIREMENTS.

Conditions which are established by the regulatory agency following permit approval and which must be met by the project sponsor to continue operations.

6. FEES.

Costs incurred for obtaining and maintaining the permit.

7. APPEAL PROCESS.

Process whereby decisions made by a regulatory agency concerning permit approval/denial can be appealed.

\section{E. ADMINISTERING AGENCY}

Name of the administering agency, its address and phone number.

Name of the counterpart Federal agency, its address and phone number.

\section{APPROACH AND INTENDED PURPOSE}

The purpose is to provide a brief summary of all state-issued environmental and land-use permits which may be required for the development of energy and other natural resources. It is not intended to be a comprehensive guide to the specific requirements of each permit, but to provide a concise, easy-to-use reference on the overall State regulatory requirements a project may face. It was felt that this document would be useful not only to private developers, but to regulatory officials at the Federal, State, and local levels of government as well.

All State agencies having jurisdiction over the permits, licenses, and approvals described in this document assisted in the preparation of the permit summaries. The final draft of each permit summary was reviewed for accuracy and completeness by each responsible agency. Users of this document should be aware, however, that changes in the laws, rules and regulations, or regulatory 
personnel since the publication of this document may cause significant changes in permit requirements.

The following agencies were contacted and have individually verified the content of that portion for which they have authority:

\section{ADMINISTERING AGENCIES}

Department of State Lands

1625 Eleventh Avenue

Capitol Station

Hel ena, MT 59620

(406) $449-4560$

Department of Heal th and Environmental Sciences

Cogswell Building

Capitol Station

Helena, MT 59620

(406) 449-3454

Department of $\mathrm{F}$ ish, Wildlife and Parks

1420 East Sixth Avenue

Hel ena, MT 59620

(406) 449-3186

Board of Oil and Gas Conservation 2535 St. Johns Avenue

Billings, MT 59101

(406) 449-3742
Department of Natural

Resources and Conservation

32 South Ewing

Hel ena, MT 59620

(406) 449-4624

Department of Commerce

Capitol Station

Hel ena, MT 59620

(406) 449-3757

Montana Historical Society

225 North Roberts

Hel ena, MT 59620

(406) 449-4584

Environmental Quality Council

1209 8th Avenue

Capitol Station

Hel ena, MT 59620

(406) 449-3742 


\section{HOW TO USE THIS GUIDEBOOK}

Due to the complexity of the statutes and the applicable rules and regulations as promulgated by various agencies, it is recommended that interested parties make pre-application contact with the agencies to obtain complete information regarding permit requirements and application procedures. In addition, various Federal permits may be required. This guide does not address the issue of State regulation over Federal land, nor regulatory authority over public domain, national forest, Indian land, military land, acquired land, or Federal reservation of minerals under private surface rights. Differences that may exist in the applicability of State law to various categories of Federal land must be addressed on an individual basis by the applicant.

This guide serves as a general reference source and should not be used as a substitute for legal advice. The information herein was collected and verified during the Summer of 1981 and includes legislation as of the end of the 1981 Session. 


\section{STATE POLICY AND PROCEDURES FOR}

CONSOLIDATED PERMIT PROGRAM 
STATE ENVIRONMENTAL POLICY STATUTES

\section{INTRODUCTION}

"There are over 30 departments, divisions and bureaus of State government involved in environmentally related regulation, enforcement and planning. The Montana Environmental Policy Act (MEPA) addresses the environment as a whole, and directs State agencies to improve and coordinate existing programs and functions in order to protect and enhance the quality of the human environment."

MEPA provides a broad statement of policy and requires that every major State government action significantly impacting the quality of the environment be preceded by a detailed environmental impact statement.

The Environmental Quality Council (EQC) oversees the impact statement process and advises the legislature, the governor, and the public on the effect of State programs, on the quality of, and trends in, the environment.

\section{A. NAME OF ACTION}

Environmental Impact Statement (EIS) and a Preliminary Environmental Review (PER) to determine the requirements of an EIS.

\section{B. AUTHORIZING STATUTE}

Montana Environmental Policy Act (MEPA), Sec. 75-1-324, MCA.

\section{TITLE OF REGULATION}

Uniform Rules Implementing the Montana Environmental Policy Act.

\section{SUMMARY OF PROCESS}

\section{APPLICABILITY.}

All agencies of the State using an interdisciplinary approach must identify and develop methods and procedures for including statements significantly affecting the environment for projects, programs, legislation and other actions to the fullest extent possible. These requirements are supplemental to existing State agency authorizations. 
2. GENERAL REQUIREMENTS.

Directs State agencies to improve and coordinate existing programs and functions to protect and enhance the human environmental quality.

3. SUBMISSION REQUIREMENTS.

A preliminary environmental review (PER) is an analysis to detemine whether an environmental impact statement is required. If the PER shows a potential effect on the environment, an EIS is prepared. The EIS can take several different forms outlined in the rules: a draft environmental impact statement; a final environmental impact statement; or, a joint environmental impact statement, and follows general EIS requirements of a description, evaluation and source material used in its preparation.

4. PROCEDURE.

A PER is prepared by the department where the action is clearly a major State action having a significant impact. (A list of those activities or functions falling in this category is maintained by the department). Copies are distributed by the department to appropriate local, State and Federal agencies, and to a public mailing list.

a. REVIE W AND PROCESSING TIME.

Depending on the comments received, the draft EIS may satisfy requirements for a final EIS and remove all further time restrictions after 15 days from sending copies of comments received. The applicant may request a time extension to respond to comments received.

If a final EIS is required, a comment period of 30 to 45 days is established for reply. The applicant has a reasonable time to respond. Unless time restrictions are removed, no action will be taken sooner than 60 days after transmittal to appropriate agencies. No board or department will take approval action sooner than 30 days after transmittal. Reasonable response 
time is allowed by the applicant. These same time periods apply to joint EIS.

Permitting action may be taken in an emergency situation without an EIS.

b. PUBLIC NOTIFICATION, HEARINGS.

When a hearing is held on an EIS, it shall be held after circulation of the draftEIS and prior to final EIS preparation.

5. OPERATION REQUIREMENTS.

By State policy, cooperative efforts are a continuing responsibility of State agencies.

6. FEES.

When the department expects to incur expenses in excess of $\$ 2,500$ in preparation of an EIS, the applicant is required to pay a fee as determined by the department.

Fee limitations are from 2 percent of estimated costs up to $\$ 1,000,000$, to $1 / 8$ of 1 percent in excess of $\$ 300,000,000$. No fees may be assessed for an application for a certificate under the Montana Facility Siting Act (See Chapter 4.1).

7. APPEAL PROCEDURES.

For fee assessed, if believed excessive, the applicant may request a hearing before the agency or board responsible for the particular action or permit.

E. ADMINISTERING AGENCY

Environmental Quality Council

Capitol Station

Hel ena, MT 59620

(406) 449-3742

\section{FEDERAL COUNTERPART}

Council on Environmental

Quality

722 Jackson Place NW

Washington, D.C. 20006

(202) $395-5770$

NOTE: Each executive branch is required to address the Environmental Quality act. The above agency does not administer the Act, as such 


\section{SECTION 3.0}

RESOURCE EXTRACTION 


\section{CHAPTER 3.1 \\ COAL AND URANIUM MINING AND RECLAMATION}

\section{INTRODUCTION}

The Department of State Lands administers mined land reclamation laws for coal and uranium activity, hard rock activities (See Chapter 3.2), opencut-mining operations (See Chapter 3.3), and has developed extensive rules and regulations to clarify its procedures.

\section{A. NAME OF PERMITS}

Strip or Underground Mining Permit.

Prospecting Permit.

\section{B. STATUTORY AUTHORITY}

Montana Strip and Underground Mine Reclamation Act, 82-4-2 MCA.

\section{TITLE OF REGULATION}

Strip and Underground Mine Reclamation Rules and Regulations 26.4.3 through 13. Administrative Rules of Montana.

\section{SUMMARY OF PERMIT PROCESS}

1. APPLICABILITY.

The law and regulations apply to the prospecting and mining of coal and uranium and the reclamational surface concurrently with disturbance. Both surface and underground mining activities are included.

\section{GENERAL REQUIREMENTS.}

An operator may not engage in strip or underground mining without having first obtained from the department a permit designating the area of land affected by the operation and anticipated to be affected during an applicable 5-year renewable permit period. A prospecting permit follows the general requirements for a mining permit and is valid for a renewable I-year period. 
3. SUBMISSION REQUIREMENTS.

Complete and detailed plans and maps for the mining, topsoil salvage, regrading, revegetation, air and water protection, and other environmental activities of the land and water to be affected by the operation. The plan must reflect thorough advance investigation and study by the operator and include all known or readily discoverable past and present uses of the land and water to be affected and the approximate periods of such prior or existing use.

4. PROCEDURE FOR OBTAINING PERMIT.

Generally the operator will have pre-application meetings with the department concerning collection of environmental resources information and other permit application requirements. The department must notify the applicant within 120 days after submission of a complete application if it is acceptable or not. This period may be extended 120 days upon notification from the department. Upon receipt of a complete application for coal mining involving Federal lands, a technical analyses is prepared and submitted to the U.S. Office of Surface Mining. Extensive public notice requirements determine the need for public hearings at various stages of the application review procedure.

\section{OPERATIONS REQUIREMENTS.}

An operator must file an annual report indicating mining operations and reclamation work undertaken. Changes in the mining and reclamation plans may be required by the department to insure compliance with the statutes and regulations.

6. FEES.

A Strip or Underground Mining Permit - $\$ 50$ permit fee. Prospecting Permit - $\$ 100$ permit fee. Reclamation performance bonds or other acceptable surety must be submitted for both mining and prospecting operations. 
7. APPEAL PROCESS.

An applicant may file a new reclamation plan if the permit is denied.

E. ADMINISTERING AGENCY

Reclamation Bureau

Department of State Lands

1625 Eleventh Avenue

Capitol Station

Helena, MT 59620

(406) $449-4560$

\section{FEDERAL COUNTERPART}

Office of Surface Mining U.S. Department of Interior 1020 - 15th Street

Denver, CO 80202

(303) $837-5421$ 
CHAPTER 3.2

METALLIFEROUS AND OTHER HARD ROCK MINING AND RECLAMATION

\section{INTRODUCTION}

The Department of State Lands is responsible for the administration of exploration and operations of metalliferous mines, limestone quarries and other quarries, and oil shale. The department also administers coal and uranium mining and reclamation laws (see Chapter 3.1) and reclamation of opencut-mining operations (see Chapter 3.3).

A. NAME OF PERMIT

Operating Permit. Exploration License. Small Miner Exclusion Statement.

\section{B. STATUTORY AUTHORITY}

Metal Mine Reclamation Act 82-4-3 MCA.

\section{TITLE OF REGULATIONS}

Rules and Regulations Governing the Montana Metal Mine Reclamation Act 26-4-1. Administrative Rules of Montana.

\section{SUMMARY OF PERMIT PROCESS}

1. APPLICABILITY.

Mining and exploration for any ore, rock, or substance, other than oil, gas, bentonite, clay, coal, sand, gravel, phosphate rock, or uranium, taken from below the surface or from the surface for the purpose of milling, concentration, refinement, smel ting, manuf acturing, or other subsequent use or process or for stockpiling for future use, refinement, or smelting within the boundaries and lawful jurisdiction of the State.

2. GENERAL REQUIRMENTS.

The act requires permits to mine and licenses to explore for minerals with the basic purpose being the conservation and reclamation of the 
land for subsequent beneficial use. "Small miners" not removing in excess of 36,500 tons in any calendar year, disturbing less than 5 surface acres, or for two operations at least 1-mile apart and operated seasonably disturbing less than 5 acres each, are exempt provided a written agreement is entered into with the department. (Small Miner Exclusion Statement). An annual exploration license is required prior to exploration and requires surface reclamation.

3. SUBMISSION REQUIREMENTS.

Application for operating permits and exploration licenses require submission of maps and plans of the mining activity and operating procedures and a reclamation plan. Small miner exclusion statements also must be submitted with a location map.

4. PROCEDURE FOR OBTAINING PREMIT.

Applications are reviewed for completeness and the applicant notified of completeness within 30 days of receipt. A decision must be made within 30 days of the receipt of a complete application or within 60 days of receipt of the application if the department does not notify the applicant of deficiencies. An operating permit cannot be issued before receipt of bond. Extension of time for on site inspection and review is not to exceed 180 days, as determined by the department. Decision on major operations requiring the preparation of an environmental impact statement may be extended for up to 365 days by negotiated agreement.

5. OPERATING REQUIREMENTS.

The operator must comply with the reclamation plan and the board's rules.

6. FEES.

Operating Permit - \$25.

Exploration License - \$5.

Small Miner Exclusion Statement - No charge. 
In addition, a reclamation preformance bond or other acceptable surety must be filed with the department for operating permits and expl oration licenses.

7. APPEAL PROCESS.

An applicant may file a new reclamation plan if the permit is denied.

E. ADMINISTERING AGENCY

Hard Rock Bureau

Reclamation Division

Department of State Lands

1612 Eleventh Avenue

Capitol Station

Helena, MT 5960I

(406) $449-4560$

\section{FEDERAL COUNTERPART}

Bureau of Land Management

222 N. 32nd S treet

P. O. Box 30157

Billings, MT 59107

(406) $657-6474$ 
CHAPTER 3.3

\section{CONSTRUCTION MATERIALS MINING AND RECLAMATION}

\section{INTRODUCTION}

The Department of State Lands administers mined I and reclamation laws for opencut-mining operations except operations on Federal lands, where the Board of Land Commissioners determines that reclamation controls are equal or greater than those administered by the department.

\section{A. NAME OF APPROVAL}

Mined Land Reclamation Contract

\section{B. STATUTORY AUTHORITY}

The Opencut Mining Act 82-4-4 MCA.

\section{TITLE OF REGULATION}

Rules and Regulations Governing The Opencut Mining Act. Administrative Rules of Montana 26.4.2.

\section{SUMMARY OF APPROVAL PROCESS}

I. APPLICABILITY.

Any operator conducting and opencut mining operation or a number of operations for sand, gravel, bentonite, clay, scoria or phosphate rock resulting in the removal of 10,000 cubic yards or more, of product or overburden, is required to obtain a mined land reclamation contract from the department. Underground phosphate operations must also obtain a reclamation contract to insure reclamation of above ground disturbance.

2. GENERAL REQUIREMENTS.

An approved mined land reclamation contract between the board and the applicant is required before an operator may commence mining. 
3. SUBMISSION REQUIREMENTS.

An application for contract form, bond or security, fee, detailed reclamation plan, and maps of the intended operation. For most bentonite specifically and large projects generally, soils and overburden surveys are required together with vegetation and archaeology and four seasons wildlife surveys.

4. PROCEDURE FOR OBTAINING APPROVAL.

A pre-application meeting is recommended, to assist the opertor in developing a reclamation plan. Upon receipt of a complete application, as determined by the department, technical review is performed and a final decision rendered within 60 days (generally less). Public hearings or meetings are held only when concern over the operation is expressed following required public notice (once a week for 3 weeks). The department submits the plan to the State Archaeological Survey for evaluation of possible archaeological or historical values. Once the reclamation plan is accepted in writing by the department, it becomes a part of the contract subject to annual review and modification by the department.

5. OPERATIONS REQUIREMENTS.

Annual progress reports on forms furnished by the department are required indicating acres affected and reclamation accomplished, and area to be mined. Operator nust maintain adequate bond; must follow approved reclamation; and, must operate within confines of contracted acreage.

6. FEES.

$\$ 50$ plus reclanation bond not less than $\$ 200$ nor more than $\$ 1,000$ per acre.

7. APPEAL PROCFSS.

A person aggrieved by a final decision is entitled to a hearing before the Board of Land Commissioners. The Montana Administrative Procedure Act governs hearings and judicial review. 
E. ADMINISTERING AGENCY

Opencut Mining Bureau

Reclamation Division

Department of State Lands

Capitol Station

Helena, MT 59601

(406) $449-4560$

\section{FEDERAL COUNTERPART}

Bureau of Land Management

222 N. 32nd Street

P. O. Box 30157

Billings, MT 59107

(406) $657-6474$ 
CHAPTER 3.4

GEOTHERMAL

\section{INTRODUCTION}

The State Board of Land Commissioners is authorized to grant leases on State-owned land "for prospecting, exploration, well construction, and the production of geothermal resources." The Department of Natural Resources and Conservation, Energy Division, has prepared a "Geothermal Handbook" explaining in some detail the $S$ tate and Federal agency regulations, permits and financial aids available for geothermal development. Other State, Federal, and local permits may be required and a potential developer must contact other regulatory agencies prior to exploration and development. This chapter summarizes State requirements within the jurisdiction of the board.

\section{A. NAME OF PERMIT AND APPROVAL}

Lease for exploration or development - by sealed bid (if only one application, then by negotiation with the department).

B. STATUTORY AUTHORITY

Geothermal Resources 77-4 MCA

\section{TITLE OF REGULATIONS}

Geothermal Resources 26-2.6 (2).

Administrative Rul es of Montana.

\section{SUMMARY OF PERMIT/APPROVAL PROCESS}

I. APPLICABILITY.

Leases are limited to 640 acres per lease and are required prior to exploration or production of geothermal development. Minimum requirements are established for operations, abandonment procedures (reclamation) and waste disposal.

2. GENERAL REQUIREMENTS.

A successful lease applicant is issued a primary 10-year term lease 
extendable on basis of drilling or production. Requirements of other State and Federal departments and agencies, as they may relate to exploration and development, should be determined prior to lease application. (In particular the State Environmental Quality Council, the Departments of Health and Environmental Sciences, Highways, Public Service Regulation, State Lands, and Fish, Wildlife, and Parks, and any local governing bodies in the areas aff ected.)

\section{SUBMISSION REQUIREMENTS.}

Application must include detailed information on the operator, location of operations, starting and estimated completion dates, size, scope and methods of operation and reclamation plans. Additional submission requirements including an environmental impact statement are part of the review process. (See Chapter 2.1).

\section{PROCEDURE FOR OBTAINING APPROVAL.}

An application is filed with the department with the nonrefundable fee. "At the Commissioner's discretion," a public lease sale is announced when sufficient applications are received.

\section{OPERATIONS REQUIREMENTS.}

Annual reports detailing all exploration activities, expenditures, and sales reports. Exploration expenses must equal 4 times the yearly rental after the third year of the lease term. If diligent exploration is not occurring, a delayed exploration penalty is assessed (at least $\$ 2$ per acre). Failure to diligently explore or to pay the penal ty may cause the lease to be cancelled. Notification and permission requirements must be met prior to geophysical seismic exploration using explosives, and reports filed with the county clerk and recorder within 3 months after each firing. Royal ty payment of 10 percent of gross revenue from sales plus 2 to 5 percent of by-product revenue (10 percent for health or recreation purposes revenue) plus at least $\$ 2$ per acre for commercial quantity discovery. 
6. FEES.

Lease application - $\$ 10$ plus 1/5 of first year's rental to be returned if the bid is unsuccessful. If lease is granted a $\$ 25$ fee plus the remaining 4/5 of first year's rental.

Deep well (1,000 feet or more) - $\$ 10,000$ bond.

Seismic exploration using explosives - $\$ 5,000$ plus surety bond of $\$ 10,000$ for I crew; $\$ 25,000$ for 2 or more crews.

\section{E. ADMINISTERING AGENCY}

\section{Geothermal Program}

Department of Natural

Resources \& Conservation

32 South Ewing

Helena, MT 59620

(406) 449-4624

\section{FEDERAL COUNTERPART}

Division of Geothermal Energy

Department of Energy

Idaho Falls, ID 8340 I

(208) 526-0638 
CHAPTER 3.5

OIL AND GAS

\section{INTRODUCTION}

The Board of Oil and Gas Conservation, within the Department of Natural Resources and Conservation, has primary responsibility for the regulation of oil and gas drilling in the State. The Board of Land Commissioners in the Department of State Lands may issue leases for oil and gas exploration on State lands, and the Boards of County Commissioners and School District Supervisors may lease their locally owned lands for similar purposes.

\section{A. NAME OF PERMIT}

Permit to Drill for Oil, Gas Permit Exploratory Strat or Core Hole.

B. STATUTORY AUTHORITY

Board of Oil and Gas Conservation, Section 2-15-3303, MCA. Oil and Gas Act Section 82-11, MCA.

\section{TITLE OF REGULATION}

General Rules and Regulations Relating to Oil and Gas, 36.20.101 through 36.22.1611, Administrative Rules of Montana (ARM).

\section{SUMMARY OF PERMIT PROCESS}

I. APPLICABILITY.

Regulations apply to oil or gas exploration, drilling, production, transportation, refining and extraction plants, and abandonment, plugging and surface restoration. Plugging exceptions may be made for fresh water wells.

2. GENERAL REQUIREMENTS.

Permits for seismic exploration are issued for 1-year by the county clerk and recorder. Reclamation bonds are required to assure proper plugging and cover, and to avoid adverse environmental impacts. 
Drilling permits from the board of oil and gas conservation, valid for 90 days with one 90 day extension, are required prior to drilling an oil or gas well and are issued by the petroleum engineer. Well spacing may be ordered by the board to prevent waste and to insure efficient extraction.

3. SUBMISSION REQUIREMENTS.

Various forms are available from the petroleum engineer for filing applications and making reports and requests. Form numbers:

1 - Organization Report;

2 - Sundry Notice and Report of Wells;

3 - Bond;

4 and $4 \mathrm{~A}$ - Completion Report;

5 - Report of Subsurface Injections;

6 and $6 \mathrm{~A}$ - Report of Production

7 - Transportation Agency's Monthly Report of Receipts and disposition of Crude oil;

8 - Refiner's Monthly Report of Receipts and Disposition of Crude Oil;

9 - Monthly Gas Report;

10 and I0A - Gasoline or other Extraction Plant;

11 - Reservoir Survey Report and Gas - Oil Ratio;

12 - Producers Payment of Oil and Gas Production Tax;

13 - Producers Certificate of Compliance and Authorization to Transport Oil or Gas from Lease;

14 - Certificate of Deposit Cash Bond.

4. PROCEDURE FOR OBTAINING PERMIT.

Application with a certified surveyor's plat, fees and bond are reviewed for compliance with the rules and regulations and a permit issued immediately after submission requirements are satisfactorily met. 
5. OPERATIONS REQUIREMENTS.

An operator must file copies of electric logs, core data, drill stem tests, sample descriptions, and reports of any other work done on the well. Sundry notices, completion reports, and production reports are also required: on completion or abondonment, solid drilling waste and salt or brakish water disposal, fire hazard prevention, water production and injection processes. Monthly reports are required to identify well, production and sales.

6. FEES.

Seismic exploration - None.

Permit to Drill:

(a) Estimated well depth of 3,500 feet or less - \$25;

(b) 3,50 I to 7,000 feet - $\$ 75$;

(c) 7,001 feet or deeper - $\$ 150$.

Plugging and Restoration Bond -

(a) Each well drilled to any depth - $\$ 5,000$;

(b) More than one well - $\$ 10,000$.

Increases in bonding may be required when factual situations are warranted in the opinion of the board.

7. APPEAL PROCESS.

Exception to the Rules and Regulations are taken before the board.

\section{E. ADMINISTERING AGENCY}

Board of Oil \& Gas Conservation 2535 St. Johns Avenue

Billings, MT 59102

(406) $656-0040$

\section{FEDERAL COUNTERPART}

U.S. Geological Survey

3 Seventh Street, West

P. O. Box 2550

Billings, MT 59103

(406) 657-6367 
SECTION 4.0

\section{LAND USE REGULATION}




\section{SECTION 4.0 LAND USE REGULATION \\ CHAPTER 4.1 \\ MAJOR FACILITY SITING}

\section{INTRODUCTION}

Location, construction, and operation of major facilities or additions thereto engaged in the generation, distribution or conversion of energy must receive a certificate of environmental compatibility and public need from the Board of Natural Resources and Conservation. In addition, the people of Montana determine whether a nuclear facility will be constructed.

\section{A. NAME OF CERTIFICATE}

Certificate of Environmental Compatibility and Public Need.

\section{B. STATUTORY AUTHORITY}

Montana Major Facility Siting Act MCA 75-20-101 et.seq.

\section{TITLE OF REGULATION}

Major Facility Siting Rules, 36.7.101. Administrative Rules of Montana (ARM).

\section{SUMMARY OF PERMIT PROCESS}

I. APPLICABILITY.

The regulatory requirements apply to the location, construction and operation of energy generation conversion, transmission and pipeline facilities, including hydropower, coal conversion and generation, nuclear power generation, electric transmission lines and gas, water liquid hydrocarbon pipelines, but excluding crude oil and natural gas refineries and pipelines and those facilities subject to the Montana Strip and Underground Mine Reclamation Act.

The following facilities or additions there to having an estimated cost in excess of $\$ 10$ million are under the jurisdiction of the Act:

a. generating 50 megawatts of el ectricity or more;

b. producing 25 million cubic feet or more of gas per day derived from coal; 
c. producing 25,000 barrels of liquid hydrocarbon products per day or more;

d. enriching uranium minerals;

e. utilizing or converting 500,000 tons of coal per year or more;

and in addition the following facilities and their associated facilities:

f. each electric transmission line of a design capacity of more than 69 kilovolts (not including facilities of a design capacity of 230 kilovolts or less and 10 miles or less in length);

g. each pipeline designed for or capable of transporting gas (except natural gas), water, or liquid hydrocarbon products from or to a facility located within or without the State of Montana in "a" through "e" above;

h. any use of geothermal resources, including the use of underground space in existence or to be created for the creation, use, or conversion of energy, designed for or capable of producing geothermally derived power equivalent to 25 million BTU per hour or more or any addition having an estimated cost in excess of $\$ 750,000$; or

i. any underground in situ gasification of coal.

\section{GENERAL REQUIREMENTS.}

Any person contemplating construction of a facility within the ensuing 10 years must furnish annually to the Department of Natural Resources and Conservation a long-range plan for construction and operation of the facilities.

No one may commence to construct a facility without making application to and receiving a certificate from the board. A certificate cannot be issued for a nuclear facility unless approved by a majority of voters in a statewide election.

\section{SUBMISSION REQUIREMENTS.}

An applicant may file a notice of intent at least 12 months prior to 
the filing of an application and be entitled to a 5 per cent reduction of the filing fee.

An application must include baseline data for the preferred and a reasonable alternate site location, an analysis of need for the proposed facility (except non-utilities do not have to supply a need analysis) and an analysis of alternatives (energy sources, technologies and locations). Copies of the application must be made available to applicable local jurisdictions and Federal agencies, and to the State Environmental Quality Council and State Departments of Public Service Regulation; Fish, Wildlife, and Parks; State Lands; Commerce; Highways; and Revenue.

4. PROCEDURE FOR OBTAINING CERTIFICATE.

A long range plan must be filed with the Department of Natural Resources and Conservation and the Department of Health and Envirommental Sciences at least 2 years prior to the anticipated acceptance date of an application. Early pre-application meetings are encouraged in the facility planning process. Applications are filed with the Department of Natural Resources and Conservation (DNRC) and the Department of Health and Environmental Sciences (DHES). Following a 90 day review period the DNRC must determine if the application is complete and accepted or incomplete and reject it with a list of deficiencies. Upon resubmittal of the application, the DNRC and DHES have 30 days to review and accept or reject the application. An environmental study by the DNRC is completed in a maximum time period of 22 months (except for transmission lines between 30 or less miles in length, 12 months are allowed). The DHES takes 12 months and may take an additional 6 months for the DHES or Board of Health and Environmental Sciences to determine compliance with laws administered by the DHES. DNRC findings are reported to the Board of Natural Resources which schedules a hearing within 120 days of receipt of the findings (a pre-hearing conference is scheduled within 60 days). 
A recommended report and order of the examiner is provided no more than 60 days from the hearing and the final decision with conditions by the board is made within 60 days from the examiner's recommended decision. The total board process is to be completed within 11 months af ter studies and recommendations by the DNRC.

5. OPERATIONS REQUIREMENTS.

Certificates may be revoked for failure to meet safety standards or failure to comply with any other conditions imposed by the board or for material false statements if a true statement would have warranted the board's failure to grant a certificate, or for violation of any provision of the statutory authority, the rules issued thereunder, or orders of the board.

6. FEES.

A filing fee may be paid in installments for the department's processing an application but shall not exceed the following scale based on the estimated costs of the facility. (The fee is refundable if not expended by the DNRC.):

a. 2 percent up to $\$ 1$ million; plus

b. I percent over $\$$ I million and up to $\$ 20$ million; plus

c. 0.5 percent over $\$ 20$ million and up to $\$ 100$ million; plus

d. 0.25 percent over $\$ 100$ million and up to $\$ 300$ million; plus

e. 0.125 percent over $\$ 300$ million.

Credits may be allowed at the DNRC's discretion for information or services required for preparation of an environmental impact statement.

\section{APPEALS PROCESS.}

Judicial review by any active party may be obtained in a State district court in accordance with the Montana Administrative Procedures Act. 
E. ADMINISTERING AGENCY

Facility Siting Division

Department of Natural Resources and Conservation

32 South Ewing

Helena, MT 59620

(406) $449-4650$
FEDERAL COUNTERPART

Federal Energy

Regulatory Commission 825 N. Capitol Street, NE

Washington, D.C. 20426

(202) 357-8055 


\section{CHAPTER 4.2}

\section{LAND USE}

\section{INTRODUCTION}

The Subdivision Bureau, Environmental Sciences Division of the Department of Health and Environmental Sciences (DHES) has subdivision review responsibility for water supply, disposal of sewage and solid waste unless exempt under the master plan exclusion. The master plan exclusion can apply when the subdivision falls within the comprehensive plan of a municipality and the local jurisdiction certifies that municipal water supply and sewage disposal facilities will be provided.

\section{A. NAME OF APPROVAL}

Certificate of Subdivision Plat Approval.

\section{B. STATUTORY AUTHORITY}

Sanitation in Subdivisions Act. 76-4-101, through 131, MCA.

\section{TITLE OF REGULATION}

Subdivision Application and Review, 16.16.101 through 805.

Administrative Rules of Montana.

\section{SUMMARY OF APPROVAL PROCESS}

I. APPLICABILITY.

Any subdivision creating parcels of less than 20 acres in size and not exempted under the master plan exclusion. Permanent multiple space for mobile home and recreation camping vehicle parks and condominiums are included in the definition of subdivisions.

2. GENERAL REQUIREMENTS.

Until the subdivision is certified by the local governing body that municipal facilities are to be provided and the DHES has indicated the subdivision is subject to no restrictions, a subdivision plat may not be filed, lots sold, nor construction begun. Large subdivisions 
may require preparation of an environmental impact state (See Chapter 2.1).

3. SUBMISSION REQUIREMENTS.

Copy of the subdivision plat and other documentation showing the plan of development, including the water supply system, sewage treatment, solid waste disposal, and storm water runoff are submitted concurrently to the DHES and local planning board. The agency receiving the application is responsible for forwarding it to the other.

4. PROCEDURES FOR OBTAINING APPROVAL.

Subdivision plats with the required plans are reviewed by both the State and local jurisdiction, and are required to be approved or denied by the DHES within 60 days. 120 days are required if an environmental impact statement is prepared.

5. OPERATIONS REQUIREMENTS.

The operator of public sewer and water systems must be licensed.

6. FEES.

$\$ 30$ per parcel maximum. An additional fee may be requested when preparation of environmental impact statement is required.

7. APPEAL PROCESS.

If application is denied, additional information is resubmitted and generally reviewed within 10 days. Appeal may be taken before the board, pursuant to the Montana Administrative Procedure Act.

\section{E. ADMINISTERING AGENCY}

Subdivision Bureau

Environmental Sciences Division

Department of Heal th and

Environmental Sciences

Cogswell Building

Helena, MT 59620

(406) 449-3946

\section{FEDERAL COUNTERPART}

Department of Housing and Urban Development

Federal Building

1961 Stout Street

Denver, CO 80202

(303) $837-3811$ 
CHAPTER 4.3

FLOOD PLAIN MANAGEMENT

\section{INTRODUCTION}

The Floodplain Management Section, Water Resources Division of the Department of Natural Resources and Conservation, assists in adoption and administration of local flood plain regulations after establishment and designation of flood plain areas by the Board of Natural Resources and Conservation.

\section{A. NAME OF PERMIT}

Floodplain Development

B. STATUTORY AUTHORITY

The Montana Floodplain and Floodway Management Act of 1971. 76.5 MCA.

\section{TITLE OF REGULATION}

Floodplain Management - Engineering Bureau, Chapter I5, Department of Natural Resources and Conservation. Administrative Rules of Montana.

\section{SUMMARY OF PERMIT PROCESS}

I. APPLICABILITY.

Floodplain management standards are applicable to communities participating in the State floodplain management program and/or the National Flood Insurance Program.

2. GENERAL REQUIREMENTS.

Artificial obstruction and nonconforming uses within a designated floodway or floodplain require a permit from the local floodplain administrator, or from the department if the local authorities have not adopted regulations, prior to any use or alteration being initiated within an identified 100 year floodplain. 
3. SUBMISSION REQUIREMENTS.

Plans in duplicate showing:

(1) Nature, location and el evation of the site.

(2) Existing and proposed structure locations, fill, storage or materials site.

(3) Flood proofing measures, proposed first floor el evation.

(4) External structure dimensions, finished road grade elevations.

(5) Water well and individual sewage treatment and disposal site location.

(6) Floodproofing specifications.

4. PROCEDURE FOR OBTAINING PERMIT.

Permit applicants furnish submission data as deemed necessary by the floodplain administrator and is deemed automatically granted 60 days after receipt of the application, unless notified of denial, or conditional approval, or requirement of additional information.

5. OPERATIONS REQUIREMENTS.

Applicable regulations must be followed with conditions imposed by the local floodplain administrator deemed suitable to the use of the particular site. Applicants receiving permits are required to furnish, at the time of an on-site conformance inspection, certification by a registered professional engineer or licensed land surveyor of the actual lowest floor elevations and floodproofing techniques utilized and their el evations.

6. FEES.

Set by local jurisdictions - - not to exceed \$25.

7. APPEAL PROCESS.

Aggrieved party may appeal the floodplain administrator's decision to a court of record. Floodplain map accuracy may be appealed to 
the Floodplain Management Section of the department, or the Insurance and Mitigation Division, F.E.M.A. (See Federal Counterpart below).

\section{E. ADMINISTERING AGENCY}

Appropriate local Political Subdivision

Floodplain Management Section Water Resources Division Department of Natural

Resources \& Conservation

32 South Ewing

Helena, MT 59620

(406) 449-2872

\section{FEDERAL COUNTERPART}

Insurance and Mitigation Division Federal Emergency Management Agency - Region VIII Denver Federal Center Building 710

Denver, CO 80225

(303) 234-6582 


\title{
SECTION 5.0
}

\section{ENVIRONMENTAL QUALITY}

\author{
MANAGEMENT
}


CHAPTER 5.I

AIR QUALITY

\section{INTRODUCTION}

The Air Quality Bureau of the Montana Department of Health and Environmental Sciences is responsible for administration of the Federal and the State's air pollution control program. Local health officials may act in conjunction with the department and may be delegated review authority in some instances.

\section{A. NAME OF PERMIT}

Air Quality Permit Application for Sources of Air Pollution.

\section{B. AUTHORIZING STATUTE}

Clean Air Act of Montana, Title 69, Chapter 3904 through 3923, RCM 1947. (Abatement of Smoke Nuisances, Title II Chapter 250 I through 25 II RCM 1947 authorizes local jurisdictions abatement contracts.)

\section{TITLE OF REGULATION}

Montana Air Quality Rules, MAC 16-2.14(1)-S14040.

\section{SUMMARY OF REGULATION}

1. APPLICABILITY.

The Board of Heal th and Environmental Sciences has authority to adopt rules for the enforcement of Federal and State air quality laws. Emission limits may be more strigent than Federal requirements, and may be stricter in some local jurisdictions because of concentrations of emission sources, population, economy or land use patterns.

2. GENERAL REQUIREMENTS. Applications for permits to construct or modify any facility are preceded by publication of intent and complete application on forms provided by the bureau. 
3. SUBMISSION REQUIREMENTS.
a. Maps and diagrams showing location of proposed source, each associated stack, property involved, height and outline of buildings, and height and outline of each stack.
b. Description of source including expected production capacity, raw materials, major components, control equipment, characteristics of effluent stream, and nature and quantities of contaminants emitted.
c. Schedule of construction, normal and maximum operating schedules.

4. PROCEDURE FOR OBTAINING PERMIT.
a. Upon receipt of an application, the bureau has 30 days to notify applicant and request additional data.
b. Applicant notifies public of intent to file application with legal publication in newspaper in affected area 10 days before or 10 days after initial application.
c. Bureau prepares Preliminary Environmental Review to determine need for EIS. If no EIS, bureau makes preliminary decision on application.
d. If EIS is required, 30 days public notice of public hearing is required. If EIS is not required, interested parties are sent copies of preliminary decision at least 40 days after completed application with 15 days to comment.
e. If EIS is required, bureau makes final determination. If EIS is not required, final decision is made within 60 days.

5. OPERATIONS REQUIREMENTS.

Must follow any applicable Montana Air Quality Rules and any conditions which may be included in permit.

\section{FEES.}

Legislative authority exists but department has not as yet imposed 
fees. Fee is required for those permits requiring EIS to cover expenses of preparation by department.

\section{APPEAL PROCESS.}

Within 15 days of final decision, a person may request a hearing before the board to appeal the bureau's decision. An appeal stays the department's (bureau) decision until acted upon by the board.

\section{E. ADMINISTERING AGENCY}

Montana Air Quality Bureau

Department of Heal th and

Environmental Sciences

Cogswell Building

Helena, MT 59620

(406) 449-3454

\section{FEDERAL COUNTERPART}

U.S. Environmental Protection Agency

Federal Building, Drawer 10096

Helena, MT 49624

(406) $449-5414$ 
CHAPTER 5.2

WATER QUALITY STANDARDS AND REGULATIONS

\section{INTRODUCTION}

The Board of Health and Environmental Sciences is responsible for the classification of all State waters as defined by the Act and establishment of classifications and standards of water purity and wastewater discharge to conform to the National Pollution Discharge Elimination System. The Department of Heal th and Environmental Sciences administers the water quality regulations.

\section{A. NAME OF PERMIT}

Application For Permit To Discharge Wastewater. Montana Pollutant Discharge Elimination System (MPDES).

B. STATUTORY AUTHORITY

Montana Water Quality Act, Sections 75-5-101 through 75-5-641, MCA.

\section{TITLE OF REGULATION}

Water Quality Rules 16.20.305 through 16.20.9.9 Administrative Rules of Montana.

\section{SUMMARY OF PERMIT PROCESS}

1. APPLICABILITY.

For new, modified or additions to point sources discharging pollutants (sewage, industrial wastes or other wastes) into State waters.

2. GENERAL REQUIREMENTS.

Standard EPA application forms modified for the State are required for various discharge sources.

3. SUBMISSION REQUIRENENTS.

Water-use classifications for various river drainage basins have been established. Site plans, design conditions and process descriptions, 
construction plans and specifications and additional information that may be required by the department.

4. PROCEDURE FOR OBTAINING PERMIT.

Appropriate permit application forms must be filed no less than 180 days prior to operation (which satisfies NPDES requirements) to the State Environmental Sciences Division, U.S. Army Corps of Engineers and EPA. A tentative determination will be made by the department based on apparent compliance or noncompliance. If the determination is to deny the permit written notice is given to the applicant. If determination is to issue a permit, the department shall schedule a hearing before the board if requested, and the action of the department shall be affirmed, modified, or reversed.

5. OPERATIONS REQUIREMENTS.

Meet permit conditions including effluent limitations, self-monitoring requirements and compliance schedules.

6. FEES.

None.

7. APPEAL PROCESS.

An appeal of an order of the board shall be in the district court of the county in which the alleged source of pollution is located.

\section{E. ADMINISTERING AGENCY}

Water Quality Bureau

Department of Health and Environmental Sciences

Cogswell Building

Helena, MT 59620

(406) $449-2406$
FEDERAL COUNTERPART

U.S. Environmental Protection Agency

Montana Operations Office Federal Office Building, Drawer 10096 30 I South Park Helena, MT 59626

(406) 449-5432 
CHAPTER 5.3

\section{PUBLIC WATER SUPPLY}

\section{INTRODUCTION}

Public water supply systems regulations are administered by the Water Quality Bureau of the Department of Health and Environmental Sciences. The Department licenses laboratories for water analysis purposes.

\section{A. NAME OF APPROVAL}

Public Water Supply.

B. STATUTORY AUTHORITY

Montana Laws Regarding Public Water Supply. Sections 75-6-101 through $75-6-113$, MCA.

\section{TTLE OF REGULATION}

Public Water Supplies Rules 16-2.14(10)-S14381. Plans for Public Water Supply or Wastewater System 16.20•401.

\section{SUMMARY OF PERMIT PROCESS}

1. APPLICABILITY.

The siting, construction, operation, and modification of a public water supply system providing water for human consumption from any community well, water hauler for cisterns, water bottling plant, water dispenser, or other water supply that serves 10 or more families, 25 or more persons daily, or has at least 10 service connections at least 60 days out of the calendar year.

2. GENERAL REQUIREMENTS.

Waters are to be examined to determine their quality and the possibility that they may endanger public heal th: 
3. SUBMISSION REQUIREMENTS.

The applicant must supply the facility name, location and description of the water source; copies of plans, specifications and other information covering the proposed system.

4. PROCEDURE FOR OBTAINING PERMIT.

A completed application is reviewed by the bureau and approval issued or denied within 60 days. Resubmittal of incomplete application will start review process of denial.

5. OPERATIONS REQUIREMENTS.

Applicant must construct and operate facility in compliance with approved design.

6. FEES.

Fees are established for services rendered in analyzing water. No inspection fee.

7. APPEAL PROCESS.

Appeals are made to the district court.

E. ADMINISTERING AGENCY

Water Quality Bureau

Department of Heal th and

Environmental Sciences

Cogswell Building

Helena, MT 59620

(406) 449-2406

\section{FEDERAL COUNTERPART}

U.S. Environmental Protection

Agency

Montana Operations Office

Federal Office Building Drawer 10096

30 I South Park

Helena, MT 59626

(406) 449-5432 


\section{CHAPTER 5.4 \\ IN-SITU MINING OF URANIUM POLLUTANT DISCHARGE}

\section{INTRODUCTION}

The Water Quality Bureau of the Department of Health and Environmental Sciences administers rules to control the discharge of pollutants into groundwaters from activities associated with in-situ solution mining of uranium.

\section{A. NAME OF PERMIT.}

Montana In-situ Mining of Uranium Control System (MIMUCS), Application for Permit to Discharge.

\section{B. STATUTORY AUTHORITY}

I. Control of Uranium Solution Extraction 50-1701 et. seq. RCM 1947.

2. Montana Water Quality Act, Sections 75-5-101 et. seq.

\section{TITLE OF REGULATION}

Environmental Sciences 16-2.14 (10) - S14465, Administrative Rules of Montana.

\section{SUMMARY OF PERMIT PROCESS.}

I. APPLICABILITY.

Disposal of pollutants into waste disposal wells associated with in-situ solution mining of uranium. Also introduction of chemicals into well field for solution mining process. (Permit does not relieve applicant from liability for pollution to any person suffering damage or obligation to comply with other State and Federal laws.)

2. GENERAL REQUIREMENTS.

An owner or operator of any proposed source shall file a completed permit application no less than 180 days prior to the day on which it is desired to start operation of the system, facility, or activity which results in the direct or indirect introduction of pollutants into ground water from in-situ mining. 
3. SUBMISSION REQUIREMENTS.

Applicant submits form with general information on operator and location of mine and supplemental information on site definition; plans for process and waste storage; description of proposed monitoring program; excursion control; well completion; production facilities and procedures; restoration of affected ground water after mining is completed; closing after mining is completed; and any additional information determined necessary by the department.

4. PROCEDURE FOR OBTAINING PERMIT.

Permit application and supplemental information is reviewed by the department; pilot testing results may be required prior to issuance or denial of a permit. A tentative determination based on information submitted to deny or issue the permit is made by the department. If deterimination is to issue the permit, a draft is prepared for public notice for a period of not less than 30 days during which time written views may be submitted including a request or petition for public hearing. Any hearings are in accordance with described procedures. A final determination on issuance or denial is made by the department following the hearing or if no hearing following review of information presented. Final action on a permit application is made no later than 180 days af ter receipt of a completed application. The term of the permit shall not exceed 10 years with reissuance options.

5. OPERATIONS REQUIREMENTS.

A permit may be modified, suspended, or revoked in whole or in part during its term for cause.

6. FEES.

None.

7. APPEAL PROCESS.

No provisions are made for administrative appeal of a permit denial other than resubmittal of additional information. 
E. ADMINISTERING AGENCY

Water Quality Bureau

Department of Heal th and Environmental Sciences

Cogswell Building

Helena, MT 59620

(406) 449-2406

\section{FEDERAL COUNTERPART}

U.S. Environmental Protection Agency

Montana Operations Office

Federal Office Building Drawer 10096 30 I South Park

Helena, MT 59626

(406) 449-5432 


\section{CHAPTER 5.5 \\ SOLID WASTE MANAGEMENT}

\section{INTRODUCTION}

The Solid W'aste Management Bureau, Environmental Sciences Division, Montana Department of Health and Environmental Sciences, is responsible for solid waste management, hazardous waste, motor vehicle recycling and disposal, and the cleaning of cesspools, septic tanks and privies. This chapter summarizes the solid waste management aspect; and, Chapter 5.6, the hazardous wastes, Chapter 5.8 motor vehicle disposal. Septic tank pumper licenses are not included in this guide.

\section{A. NAME OF LICENSE}

Non-Hazardous Solid Waste Management System Licenses.

\section{B. STATUTORY AUTHORITY}

Montana Solid Waste Management Act, Section 75-10-201 through 75-10-233, MCA.

\section{TITLE OF REGULATION}

Solid Waste Manageinent Title 16, Chapter 14. Refuse Disposal Sub-Chapter 5 - Administrative Rules of Montano. Solid V'aste Management regulations are being modified to address small quantity exemptions.

\section{SUMMARY OF LICENSE PROCESS}

1. APPLICABILITY.

The non-hazardous waste management system is designed to control the storage, treatment, recycling, recovery and disposal of solid waste by discharge, injection, deposit, dumping, spilling, leaking or placing of any solid waste into or onto the land so that it or any constituent may enter the environment, emitted into the air, or discharged into any surface or ground waters. These requirements have general applicability to hazardous wastes (see Chapter 5.6). 
2. GENERAL REQUIREMENTS.

All new waste management system sites require preliminary environmental review and, if warranted, preparation of an Environmental Impact Statement (EIS). Solid waste disposal site standards must comply with site classifications for sufficient acreage, year around access, non- 100 year flood plain location, and to prevent ground and surface water or public water supply pollution, provide adequate surface drainage, suitable for reclamation and land reuse, meet general soil and hydrogeological requirements for each site classification access supervision and control, maintain earth cover material, generally meet the guidelines set forth in the EPA publication, "Sanitary Landfill Design and Operation," and solid waste transportation control. Within each site classification special requirements must also be met. An open burning permit from the department is required.

3. SUBMISSION REQUIREMENTS.

Legal description and acreage of site; pertinent water quality and geological/soil information; land use and zoning information; and an operation and maintenance plan.

4. PROCEDURE FOR OBTAINING LICENSE.

Applications are reviewed for completeness. Additional information requested by the department must be submitted within 90 days. Within 15 days after receipt of the completed application the local heal th officer is notified. The department, after review, makes a proposed decision and explains that decision by public notice circulated to the applicant, posting in the nearest post office and two other buildings serving the area, and sending one news release to an area newspaper. Comments may be submitted in writing within 30 days of the public notice and a final decision made by the department. The local heal th officer must validate the license within 15 days. 
5. OPERATIONS REQUIREMENTS.

Licenses remain in effect until surrendered or revoked and are non-transferable. The system must be maintained and operated in conformance with the requirements, and as approved by, the department and any other legal requirements imposed by other local, State, or Federal agencies. Limited salvaging may be done if to the department's satisfaction. Department inspection is authorized at reasonable hours.

6. FEES.

None.

7. APPEAL PROCESS.

If an application is denied or license revoked, an appeal before the board must be filed by the applicant within 30 days. The act does not provide the public with the right of appeal to the board.

E. ADMINISTERING AGENCY

Solid Waste Managem ent Bureau

Montana Department of Health and Environmental Sciences

Cogswell Building, Room A20 I

Helena, MT 59620

(406) $449-2821$
FEDERAL COUNTERPART

U. S. Environmental Protection Agency 1860 Lincoln Street

Denver, CO 80295

(303) $837-2224$ 


\section{CHAPTER 5.6 \\ HAZARDOUS/TOXIC WASTE MANAGEMENT}

\section{INTRODUCTION}

The Solid Waste Management Bureau, Environmental Sciences Division, Montana Department of Health and Environmental Sciences, is responsible for solid waste management, hazardous waste, motor vehicle recycling and disposal, and the cleaning of cesspools, septic tanks and privies. This Chapter summarzies the hazardous waste aspect; and, Chapter 5.5, solid waste; Chapter 5.8 motor vehicle disposal. Septic tank pumper licenses are not included in this guide.

\section{A. NAME OF PERMIT}

Permit for Hazardous Waste Treatment, Storage and Disposal Facilities; and, Manifest for Hazardous Waste Generators and Transporters.

\section{B. STATUTORY AUTHORITY}

Program of Hazardous Waste Management, Sections 75-10-202 through 75-10-204, 75-10-212, 75-10-214, 75-10-221, and 75-10-232, MCA. (Chapter 358, Montana Session Laws, 1981, SB 2 I2.)

\section{TITLE OF REGULATION}

Hazardous Waste, Title 16, Chapter 44 - Administrative Rules of Montana.

\section{SUMMARY OF PERMIT PROCESS}

I. APPLICABILITY.

The hazardous waste management system, as amended, updates Montana's hazardous waste rules to conform with amended EPA regulations and to clarify the State's rules, and is applicable to both identified materials and material not identified if the department has reason to believe the material characteristics may be hazardous by interpretation of the definitions and meeting criteria in the rules. Generation, transportation, and treatment, storage and disposal facilities are regulated by the rules of the department. The 
department has adopted by reference Federal agency rules as temporary licensure and standards for the operation of treatment, storage and disposal facilities until final rules and standards are adopted. General requirements for non-hazardous wastes are applicable (see Chapter 5.5).

2. GENERAL REQUIREMENTS.

A hazardous waste generator or transporter is required to have an EPA identification number assigned by the department or EPA before treating, storing, disposing, transporting, or offering for transportation hazardous waste. A generator or transporter who transports, or offers for transportation for off-site treatment, storage or disposal must prepare a manifest before transporting the waste off-site. Hazardous waste may be accumulated on-site without a license for 90 days or less.

Special requirements for generators generating less than 1000 kilograms of hazardous waste in a calendar month are treated separately in the rules.

Hazardous waste treatment, storage and disposal facilities are required to obtain a license prior to construction of a new facility, or temporary licensures for an existing facility.

3. SUBMISSION REQUIREMENTS.

As established by EPA regulations. See Chapter 5.5 for general requirements.

4. PROCEDURE FOR OBTAINING PERMIT.

Temporary procedures incorporating EPA application requirements have been adopted and are available from the department.

5. OPERATIONS REQUIREMENTS.

EPA requirements pending adoption of permanent requirements by the department. General requirements of solid wastes apply (see Chapter 5.5). Transporters must maintain copies of manifests for 3 
years. In the event of discharge or materials incidents of hazardous wastes during transportation notification procedures to Federal, State, and local authorities must be followed.

6. FEES.

None.

7. APPEAL PROCESS.

If an application is denied or license revoked an appeal before the board must be filed by the applicant within 30 days. The act does not provide the public with the right of appeal to the board.

\section{E. ADMINISTERING AGENCY}

Solid Waste Managem ent Bureau Montana Department of Health and Environmental Sciences Cogswell Building, Room A20I Helena, MT 59620

(406) $449-2821$

\section{FEDERAL COUNTERPART}

U. S. Environmental Protection Agency 1860 Lincoln Street Denver, CO 82095

(303) 8372224 


\section{CHAPTER 5.7 \\ NOISE REGULATIONS}

\section{INTRODUCTION}

The Montana State Department of Health and Environmental Sciences administers Occupational Noise and Occupational Air Contaminants rules within the Occupational Health Bureau of the Environmental Sciences Division. These rules are applicable to noise exposure levels and establish maximum threshold limit values for air contaminants. The noise levels apply to workers not otherwise covered by OSHA. Local authorities may establish noise control regulations as par $t$ of their airport zoning ordinances.

\section{A. STATUTORY AUTHORITY}

Occupation Health 50-70-101 et. seq. MCA.

B. TITLE OF REGULATION

Occupational Noise and Air Contaminants, Rule 16.42.101 and 102, Administrative Rules of Montana.

\section{ADMINISTRATIVE AGENCY}

Occupational Heal th Bureau Environmental Sciences Division State Department of Heal th and Environmental Sciences

Cogswell Building

Helena, MT 59620

(406) 449-3671

\section{FEDERAL COUNTERPART}

Occupational Safety and Heal th

U.S. Department of Heal th and Social Services

Room 1554 Federal Building

1961 Stout Street

Denver, CO 80294

(303) $837-3883$ 


\section{CHAPTER 5.8 \\ MOTOR VEHICLE DISPOSAL}

\section{INTRODUCTION}

The Solid Waste Management Bureau, Environmental Sciences Division, Montana Department of Health and Environmental Sciences, is responsible for solid was te management, hazardous waste, motor vehicle recycling and disposal, and the cleaning of cesspools, septic tanks and privies. This chapter summarizes the motor vehicle disposal aspect; and, Chapter 5.5, the solid waste-management, Chapter 5.6 the hazardous wastes. Septic tank pumper licenses are not included in this guide.

\section{A. NAME OF LICENSE}

Motor Vehicle Wrecking Facility, Application for License.

\section{B. STATUTORY AUTHORITY}

Motor Vehicle Recycling and Disposal 75-10-501 through 542, MCA.

\section{TITLE OF REGULATION}

Motor Vehicle Recycling and Disposal, Sub-Chapter 2, Title 16 Chapter 14 - Solid Waste Management, ARM.

\section{SUMMARY OF LICENSING PROCESS}

\section{APPLICABILITY.}

The department issues licenses to operate a motor vehicle wrecking facility buying. selling, or dealing in 4 or more vehicles per year for the purpose of wrecking, dismantling, disassembling, or substantially changing the motor vehicle form, or buying or selling secondhand parts. Each county is to have a licensed force motor vehicle graveyard for the accumulation of at least 200 junk vehicles for which the department is responsible for crushing and recycling. Individual disposal of a junk vehicle must be released by delivery of evidence of title to the department. 
2. GENERAL REQUIREMENTS.

All wrecking facilities and vehicle grave yards constructed after July 1, 1973, are required to be shielded from public view. No salvage is permitted in a county-operated motor vehicle graveyard.

3. SUBMISSION REQUIREMENTS.

Application for a license must include the location, size and legal description and a drawing showing the shielding facility and location of buildings. Certification by a local government official is required to assure compliance with local zoning and ordinances.

4. PROCEDURE FOR OBTAINING LICENSE.

Application with local zoning compliance and fee are submitted to the department. A license is issued after approval of the site location and compliance with the shielding requirements.

5. OPERATIONS REQUIREMENTS.

Every facility must maintain records and descriptions of each junk vehicle obtained with the name of the person from whom the vehicle was purchased. When a facility submits vehicles to the State disposal program a $\$ 2$ fee and records for each vehicle are surrendered to the department.

\section{FEES.}

$\$ 50$ annually for a wrecking facility.

$\$ 2$ per vehicle when department is contracted for removal to the State disposal program.

7. APPEAL PROCESS.

A department decision for a motor vehicle wrecking facility or graveyard license may be appealed to the board within 30 days after receipt of official notice of the department's decision. 
E. ADMINISTERING AGENCY

Solid Waste Management Bureau Montana Department of Health and Environmental Sciences

Cogswell Building

Helena, MT 59620

(406) 449-2821
FEDERAL COUNTERPART

None. 


\section{SECTION 6.0}

\section{SOCIAL/ECOLOGICAL PRESERVATION}


CHAPTER 6.I

NONGAME AND ENDANGERED SPECIES

\section{INTRODUCTION}

The State of Montana Department of Fish, Wildlife and Parks is responsible for nongame and endangered species, as well as other authority pertaining to taking of fish or game for scientific purposes, migratory game birds, grizzly bear, wild buffalo, and game preserves. The department has administrative regulatory authority for other areas of environmental or land use control.

\section{A. NAME OF PERMIT}

Nongame and Endangered Species Permit.

\section{B. STATUTORY AUTHORITY}

Nongame and Endangered Species, Montana Code Annotated, 87-5-101 through 87-5-112, MAC.

\section{TITLE OF REGULATION}

Nongame and Endangered Species, Administrative Rules of Montana 12.5.201 and 12.5.301.

D. SUMMARY OF PERMIT PROCESS

I. APPLICABILITY.

Management of nongame and endangered species to insure perpetuation of such species.

2. GENERAL REQUIREMENTS.

Individuals wishing to engage in the taking, possession, transportation, exportation, or shipment may apply for a permit for scientific, zoological, educational, propagation in captivity or for other specific purposes. 
3. SUBMISSION REQUIREMENTS.

Initial contact with the department is advised prior to making application for special permission for any species on the State or Federal endangered lists.

4. PROCEDURE FOR OBTAINING PERMIT.

After application is made the director requests technical review from the appropriate State division/region who recommended approval or denial to the director. The director will then issue or deny the permit. Total time -- 2 to 6 weeks.

5. OPERATIONS REQUIREMENTS.

Continued compliance with the conditions of the permit, if any.

6. FEES.

None.

7. APPEAL PROCESS.

As provided by the Montana Administrative Procedures Act.

\section{E. ADMINISTERING AGENCY}

Department of Fish, Wildlife \& Parks 1420 East 6th Avenue

Helena, MT 59620

(406) $449-3188$

\section{FEDERAL COUNTERPART}

U.S. Fish \& Wildlife Service 316 N. 26th Street

Billings, MT 59101

(406) $657-6340$ 


\section{CHAPTER 6.2}

\section{ARCHAEOLOGICAL AND HISTORICAL}

\section{INTRODUCTION}

A single Montana State agency is responsible for this function as it relates to both State and Federal cultural resource laws and regulations. The State Historic Preservation Office, Montana Historical Society, provides Montana Antiquities Act permits and provides review and comments related to Federal agency actions, as required by Federal statute. The office also advises State agencies or their applicants on State required cultural resource work.

\section{A. NAME OF PERMIT}

Antiquities Act Permit.

Consultation required by Federal law.

\section{B. AUTHORIZING STATUTE}

State Antiquities Act, MCA 22-3-401 through 22-3-442.

National Historic Preservation Act, P.L. 89-665 as amended and reauthorized. E. O. 11593.

\section{TITLE OF REGULATION}

36CFR800, Advisory Council on Historic Preservation.

36CFR, 61, 63, Department of Interior, National Park Service.

\section{SUMMARY OF REGULATIONS}

I. APPLICABILITY.

Any Federal undertaking, which is defined as a license, loan, grant, lease, permit, certification, or any specific ground or building disturbance, regardless of land ownership. Any State undertaking occurring on State-owned land.

2. a. GENERAL REQUIREMIENTS.

Documentation that the Montana State Historic Preservation Office has been contacted to provide information on known archaeological or historic sites and/or information on the likelihood of discovering cultural resources within a project area prior to final project formulation or planning. 
b. REGULATORY REQUIREMENTS.

Any project utilizing Federal funds or sanctioned by Federal permit or decision (regardless of land ownership) usually requires a professional field inventory to locate and evaluate previously unrecorded archaeological and historic sites and/or, if a survey has been conducted, an official determination of which sites identified qualify for listing in the National Register of Historic Places. Sites determined to be eligible for listing must be given active consideration in project planning, in consultation with the State Office of Historic Preservation and the Advisory Council on Historic Preservation, a Federal agency. Permits for cultural resource work on Federal land are handled by pertinent Federal agencies. Projects permitted or undertaken by State agencies on State land usually require a similar sequence of inventory, site evaluation, and mitigation planning. A State Antiquities permit is required for any resource disturbance on State land and is issued by the State Preservation Office.

3. SUBMISSION REQUIREMENTS.

a. Request for a file search to identify previously located historic and archaeological resources and information on whether a survey is needed. Applicant should submit legal location of project.

b. Written inventory report, including maps, inventory forms, photographs, summary evaluation, needed by the preservation office staff to determine the adequacy of the survey and whether sites identified qualify for listing in the National Register or for recognition as State heritage properties.

c. Development of management recommendations, mitigation plans, or avoidance options for Register eligible or State heritage properties within the project zone. 
4. PROCEDURES FOR OBTAINING PERMIT.

a. TIME REQUIREMENTS.

File search conducted in 5 working days.

Review of survey information and mitigation information within

10 days of receipt of information

5 working days for granting of State Antiquities permit.

b. PUBLIC NOTIFICATION, HEARINGS.

None.

5. OPERATIONS REQUIREMENTS.

Maintenance plan for protection of cultural resources may be needed.

6. FEES.

None currently.

E. ADMINISTERING AGENCY

State Historic Preservation Officer Montana Historical Society

225 North Roberts

Helena, MT 59620

(406) $449-4584$

\section{FEDERAL COUNTERPART}

National Park Service Rocky Mountain Regional Office Cultural Resource Program P. O. Box 25287 Denver Federal Center Denver, CO 80225

(303) $234-2560$

and

Advisory Council on

Historic Preservation 44 Union Blvd., Suite 616 Lakewood, CO 80228

(202) 254-3974 
CHAPTER 6.3

WETLANDS

\section{INTRODUCTION}

"Supervisors" of appropriate soil and water conservation districts, if any; and if not, supervisors of appropriate grass conservation districts, if any; and if not, boards of county commissioners issue permits for alteration of streambeds in Montana. The Fisheries Divison of the Department of Fish, Wildlife and Parks is responsible for the department's participation in review of private persons activities in rivers and streams.

A. NAME OF APPROVAL

Notice of Proposed Project (Form 270/271)

Board's Decision (Form 273 RI/77)

B. STATUTORY AUTHORITY

Natural Streambed and Land Preservation Act 75-7-101 et. seq., MCA and 36.2.40 I et. seq., ARM.

C. TITLE OF REGULATION

Regulations for each district are based upon model rules developed by the Department of Natural Resources and Conservation.

\section{SUMMARY OF APPROVAL PROCESS}

1. APPLICABILITY.

Any project which will alter a natural stream or its banks requires notification to the appropriate supervisors prior to commencement of any portion of the project.

2. GENERAL REQUIREMENTS.

Supervisors review proposed projects for compliance with model rules. Copies of these rules are available at each supervisor's office or the Montana Department of Natural Resources and Conservation. 
3. SUBMISSION REQUIREMENTS.

Notification for plans and specifications for projects involving streams is to be submitted to the supervisors, team recommendations are submitted to the supervisors and the project applicant.

4. PROCEDURE FOR OBTAINING APPROVAL.

The supervisors examine the proposed plans and notify the applicant within 5 days if the proposal is a project subject to their jurisdiction. If the proposal is a project representative of the department, "supervisors," and the applicant have 20 days to convene and perform an on-site inspection. The team submits a written report within 50 days to the "supervisors" and make a decision within 60 days of receipt of the application.

5. OPERATIONS REQUIREMENTS.

Applicant must conform with terms of the permit as approved by the supervisors.

6. FEES.

None.

7. APPEAL PROCESS.

After notification by an applicant of refusal to modify plans in accordance with recommendations, the disagreement may be arbitrated before an arbitration committee who shall issue a binding decision on all parties concerned.

E. ADMINISTERING AGENCY

Ecological Sevices Division

Department of Fish, Wildife and Parks

1420 E. 6th Street

Helena, MT 59620

(406) 449-2445

\section{FEDERAL COUNTERPART}

None. 
SECTION 7.0

\section{LOCAL REGULATORY POLICY}




\section{CHAPTER 7.I \\ LOCAL GOVERNMENT LAND USE AND \\ NATURAL RESOURCE CONTROL ENABLING LAWS}

\section{INTRODUCTION}

Governing bodies of any city or town, or any county or combination thereof may create a planning board to perform planning and adopt zoning and subdivision regulations; the board should be consulted prior to any energy or natural resource activity. Zoning may not prevent the complete use, development, or recovery of any mineral, forest, or agricultural resource by the owner.

\section{A. NAME OF APPROVAL}

Subdivision Plat Approval

Building Permits

Zoning Approval

B. STATUTORY AUTHORITY

Local Planning Legislation 76-1-101 through 76-1-614, MAC.

\section{TITLE OF REGULATION}

(As adopted by a local governing body).

\section{SUMMARY OF APPROVAL PROCESS}

1. APPLICABILITY.

The subdivision of land into parcels less than 20 acres are reviewed for conformance with local subdivision regulations and master plans. A building or structure may require a building permit as prerequisite to construction, alteration, or enlargement where local building regulations have been adopted. Within adopted zoning districts approval is required to erect, construct, alter, or maintain certain buildings or to carry on certain trades, industries or callings. Limitations may include height and bulk of buildings, area of yards, courts, and other open spaces, future uses of the land or buildings, and future building setback lines. 
2. GENERAL REQUIREMENTS.

Local governing bodies establish requirements and enforcement procedures for their jurisdictions.

3. SUBMISSION REQUIREMENTS.

Requirements are established locally.

4. PROCEDURE FOR OBTAINING APPROVAL.

Generally, plans and maps are required to be submitted to local planning boards or zoning commissions for recommendation to the governing body for final action.

5. OPERATIONS REQUIREMENTS.

Approval is contingent upon continued conformance to the requirements. Violations are generally punishable by fine or imprisonment.

6. FEES.

Local governing bodies may establish and collect reasonable fees for the issuance of permits.

7. APPEAL PROCESS.

A local board of adjustment may review and decide appeals and special exceptions. 


\section{E. ADMINISTERING AGENCY}

(See respective County seat or municipality)

Dillon, Beaverhead County

Hardin, Big Horn County

Chinook, Blaine County

Townsend, Broadwater County

Red Lodge, Carbon County

Ekal aka, Carter County

Great Falls, Cascade County

Fort Benton, Chouteau County

Miles City, Custer County

Scobey, Daniels County

Glendive, Dawson County

Anaconda, Deer Lodge County

Baker, Fallon County

Lewistown, Fergus County

$\mathrm{K}$ alispell, Flathead County

Bozeman, Gallatin County

Jordan, Garfield County

Cut Bank, Glacier County

Ryegate, Golden Valley County

Philipsburg, Granite County

Havre, Hill County

Boulder, Jefferson County

Stanford, Judith Basin County

Polson, Lake County

Helena, Lewis and Clark County

Chester, Liberty County

Libby, Lincoln County

Virginia City, Madison County

Circle, McCone County
White Sulphur Springs, Meagher County

Superior, Mineral County

Missoula, Missoula County

Roundup, Musselshell County

Livingston, Park County

Winnett, Petroleum County

Mal ta, Phillips County

Conrad, Pondera County

Broadus, Powder River County

Deer Lodge, Powell County

Terry, Prairie County

Hamilton, Ravalli County

Sidney, Richl and County

Wolf Point, Roosevelt County

Forsyth, Rosebud County

Thompson Falls, Sanders County

Plentywood, Sheridan County

Butte, Silver Bow County

Columbus, Stillwater County

Big Timber, Sweet Grass County

Choteau, Teton County

Shelby, Toole County

Hysham, Treasure County

Glasgow, Valley County

Harlowton, Wheatland County

Uibaux, Mibaux County

Billings, Yellowstone County 
$\int_{0}^{2}$

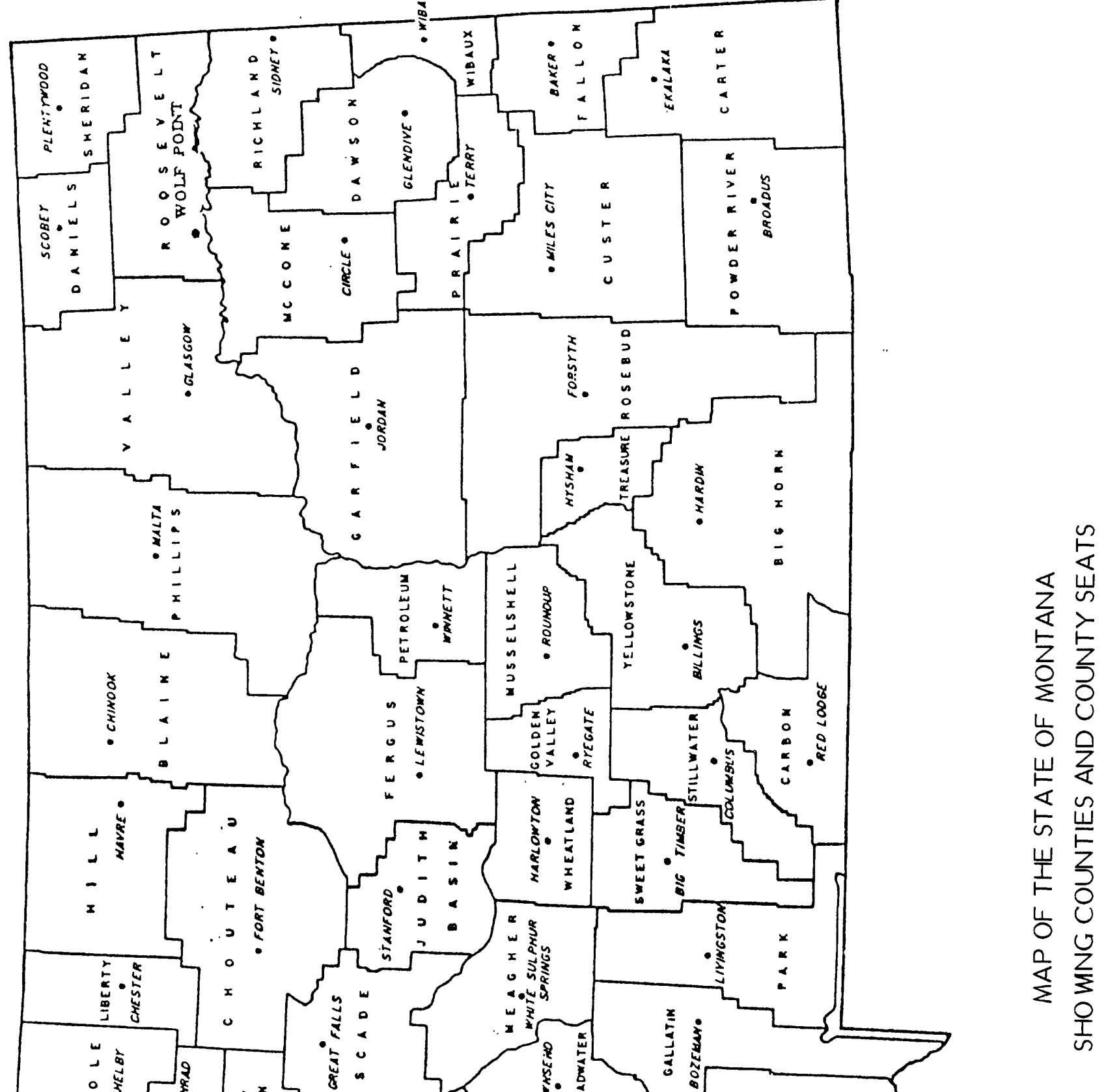




\section{CHAPTER 7.2}

\section{SUB-STATE MANAGEMENT DISTRICTS AND SPECIAL AUTHORITIES}

\section{INTRODUCTION}

Montana Statutes authorize joint land use planning among local jurisdictions. The State has designated sub-state districts although formal organizations do not exist in most districts at this time. Special purpose local governments are authorized to provide services or facilities not authoried by general purpose local governments or as an alternative method of providing service. Districts or authorities empowered to establish regulations include the following agencies:

\section{ADMINISTERING AGENGY}

Airport Authority

Conservancy District

Conservation District

Drainage District

Hospital District

Housing Authority

Irrigation District

Refuse Disposal District

School District

County Water and Sewer District

\section{STATE COUNTERPART}

Department of Commerce

Department of Natural Resources \& Conservation

Department of Natural Resources \& Conservation

District Court

Department of Heal th \& Environmental Sciences

Department of Commerce

Department of Natural Resources \& Conservation

Department of Health \& Environmental Sciences

Department of Commerce

Department of Natural Resources \& Conservation and Department of Heal th \& Environmental Sciences

Other taxing authorities or districts may exist and may perform a variety of other functions. 